\title{
KLK10 wt Allele
}

National Cancer Institute

\section{Source}

National Cancer Institute. KLK10 wt Allele. NCI Thesaurus. Code C97207.

Human KLK10 wild-type allele is located in the vicinity of $19 q 13$ and is approximately $7 \mathrm{~kb}$

in length. This allele, which encodes kallikrein-10 protein, is involved in both tumor suppression and proteolysis. 